\title{
ENTRE LA LLUNYANIA I LA INTIMITAT: L'ENUNCIACIÓ DE L'ESPAI URBÀ EN VICENT ANDRÉS ESTELLÉS
}

\author{
BETWEEN DISTANCE AND PRIVACY: \\ THE ENUNCIATION OF THE URBAN SPACE IN \\ VICENT ANDRÉS ESTELLÉS
}

\author{
Irene Mira NaVArro \\ Universitat d'Alacant \\ irene.mira@ua.es
}

Resum: L'article analitza el tractament i la presència de la ciutat en les obres de Vicent Andrés Estellés en funció de l'acostament o la llunyania que el jo poètic hi estableix. Les obres estudiades no remeten a cap període de producció concret, sinó que es troben disseminades al llarg de tota la trajectòria del poeta a causa de la presència constant que l'espai hi té. Ens centrarem, doncs, a estudiar les dues maneres que el poeta té de representar la ciutat: la que la configura com una alteritat observada pel jo poètic i la que la practica des de la proximitat. Tot fent referència als diferents indrets significatius que configuren la identitat del jo poètic.

Paraules clau: espai, ciutat, poesia, identitat, alteritat.

Abstract: This paper analyses how Vicent Andrés Estellés treats the city in his poems according to the degree of proximity between the poet and the reality on the ground. The works studied remit to any period of concrete production, but that they are disseminated along all the path of the poet because of the constant presence that the space has. We will focus on explaining the two ways that the poet has to represent the city: on the one hand when this is presented like an otherness observed by the poet and, on the other hand, when the poet lives it since the vicinity. With the aim to do reference to the different places significant that configure the identity of the poet.

Key words: space, city, poetry, identity, otherness. 
Irene Mira Navarro

Entre la llunyania i la intimitat: l'enunciació de l'espai urbà en Vicent Andrés Estellés

\section{INTRODUCCIÓ}

Podríem dir que pensar les ciutats és, en realitat, pensar les visions que el cinema, la publicitat o les arts plàstiques ens en mostren. És, en definitiva, accedir al món referencial des de les creacions que altres ulls n'han captat. Tant és així que en literatura hi ha certs noms que ens remeten involuntàriament a la ciutat que han representat en les seues pàgines. Per aquest motiu, l'objectiu que tot seguit ens proposem és explorar els mecanismes amb què es construeix el significat literari de la ciutat en l'obra de Vicent Andrés Estellés. Especialment, en referència al paper que els conceptes d'identitat i d'alteritat exerceixen en el disseny de la imatge poètica de l'espai urbà.

\section{MÉS QUE UN ESCENARI}

Dels anys setanta ençà l'estudi de com la literatura ha representat, i representa, els espais en les seues pàgines ha anat guanyant força en branques com la Literatura Comparada o els interdisciplinaris Estudis Culturals. Aquesta aproximació a cavall entre la Geografia Cultural, la Sociologia, la Filosofia, l'Antropologia i la Literatura permet acostar-se al fet literari des d'una perspectiva ampla que conjuga els diferents aspectes socials que marquen el text.

A hores d'ara disposem d'una quantitat ingent d'estudis i recerca al voltant de l'espacialitat, la seua construcció i la representació que se'n fa en els textos literaris. En aquestes anàlisis s'emfasitza la perspectiva que la ciutat és plena de significats, com afirmà Roland Barthes en La aventura semiológica (1993: 260):

\footnotetext{
La ciudad es un discurso, y este discurso es verdaderamente un lenguaje: la ciudad habla a sus habitantes, nosotros hablamos a nuestra ciudad, la ciudad en la que nos encontramos, sólo con habitarla, recorrerla, mirarla.
}

Tant és així que quasi la totalitat de les veus que estudien l'espacialitat des de les diferents disciplines coincideixen, no casualment, que l'espai és molt més que un escenari neutre on s'esdevenen les accions (Cosgrove 2002, Westphal 2007, Lefebvre 2013). Aquesta afirmació porta a interrogar-se sobre quins són els factors que el determinen i quina relació estableixen amb els subjectes que es mouen en aquest espai, bé siga urbà, domèstic o natural.

Henri Lefebvre és una de les veus cabdals en els plantejaments que guien la concepció de l'espai com un element resultant de l'acció social i no com un mer escenari on es desenvolupa el teatre del món. El filòsof francés encunyà la «fal.làcia de la 
Irene Mira Navarro

Entre la llunyania i la intimitat: l'enunciació de l'espai urbà en Vicent Andrés Estellés

transparència espacial» (2013) per a desmentir la naturalesa innocent tradicionalment atribuïda a l'espai. A partir d'aquest moment, Lefebvre defensa que, sota la suposada neutralitat, s'amaga un "orden del espacio que dista de ser tan simple y tan inocuo como quiere hacerse ver» (Martínez Lorea 2013: 22). Per tant, els espais i els llocs deixen de ser entesos com a marcs preexistents als subjectes i s'evidencia que es tracta categories definides i preparades per a desenvolupar un seguit de pràctiques previstes que condicionen la identitat, entre altres aspectes, dels subjectes.

Amb l'objectiu de fer brollar els condicionaments socials i polítics que té l'espai de la ciutat, Lefebvre defensa el dret a conquerir-lo i habitar-lo perquè esdevinga el lloc de l'experiència dels subjectes. Perquè, en definitiva, les persones s'hi reconeguen "otorgando al espacio sus múltiples dimensiones perdidas: lo transfuncional, lo lúdico y lo simbólico» (Martínez Gutiérrez 2013: 45). En el camp literari assistim a la transposició textual de les experiències i de les figuracions de l'espacialitat pròxima que configura la identitat de la veu poètica. Una configuració que té lloc gràcies a l'aproximació i el distanciament respecte dels «territoris identitaris» que són les ciutats, els barris i les cases.

\section{CREADOR D'IDENTITAT, I D'ALTERITAT}

Segons Giménez (1999), la ciutat s'entén com un indret on sedimenta la càrrega simbòlica, afectiva i cultural d'un col-lectiu, a més de ser un indret marcat per les relacions de poder que s'inscriuen en qualsevol espai (Lefebvre 2013: I49). Aquests dos condicionants de la ciutat evidencien que ens trobem davant un espai significatiu i amb identitat pròpia, que alhora marcarà la identitat de qui hi habita. És per aquest motiu que l'hem de considerar com un «lloc antropològic» amb el sentit de «lloc de la identitat compartida» que Marc Augé li va atorgar (I993: I4).

La consideració de l'espacialitat com a generadora d'identitats i com a pòsit d'aquestes enllaça amb el fenomen dialògic que Mikhaïl Bakhtín apuntava en definir la construcció identitària com un procés bidireccional. Des d'aquesta perspectiva, la identitat i l'alteritat resulten dues cares de la mateixa moneda, ja que l'altre juga un paper actiu en la constitució del nosaltres. En paraules de José Alejos: «eso a lo que llamamos identidad debe entenderse como un fenómeno de frontera, como algo que ocurre en el umbral de intersección entre yo y el otro, en el encuentro exotópico con la alteridad» (2006: 54). En la dimensió urbana aquestes afirmacions van un pas més enllà i la geògrafa Alicia Lindón explica que els subjectes no interactuen només amb altres subjectes, sinó també amb l'espai, el qual «deviene en cierta alteridad con 
Irene Mira Navarro

Entre la llunyania i la intimitat: l'enunciació de l'espai urbà en Vicent Andrés Estellés

la que se interactúa, y por lo mismo interviene en el modelado identitario» (20I4: 65). Açò ens permet atestar que identitat i alteritat són conceptes complementaris que operen al voltant dels límits entre el jo poètic i l'espai, un jo i un altre que en el cas de Vicent Andrés Estellés és la ciutat.

El vincle relacional entre aquests dos conceptes permet plantejar la idea del jo poètic com a centre i la ciutat com un element extern als nostres límits. Hem d'advertir, però, que l'alterització de la ciutat no la converteix en una amenaça per a la identitat del subjecte, sinó que es tracta d'un contrast materialitzat en termes espacials. La interioritat del jo poètic, i per consegüent de l'espai domèstic, es diferencia de l'exterioritat de la ciutat.

La representació espacial de la idea d'identitat i alteritat és un mecanisme que permet donar entitat material a uns límits conceptuals sovint difusos, concretament els límits entre subjecte-societat.

Aquest contrast d'esferes és una de les peces sobre les quals bascula la creació de Vicent Andrés Estellés, ja que les preocupacions del món són arrossegades a la intimitat discursiva de la poesia. A propòsit del poemari Colguen les gents amb alegria festes, Vicent Salvador posa de manifest aquesta peculiar naturalesa del vincle entre el jo poètic i el món, una reflexió que seria extrapolable a altres obres estellesianes. Segons l'autor, el poemari «presenta el món interior de l'escriptor, construint el record i al capdavall la seua pròpia identitat, i els confronta amb la realitat externa, la vida del carrer» (2016: 17). A tall d'exemple, els següents versos esmenten el reflex poètic de l'experiència acumulada del contacte amb l'alteritat urbana (CGAF 20I6: 77): ${ }^{1}$

i feia inexpugnable, l'ésser que fores i ets: els dies, els fracassos, com certes referències - determinats carrers que mai no oblidaràs,

I. Els poemaris apareixen citats amb les inicials. La correspondència amb el títol i el volum on es troben publicats és la següent:

CGAF: «Colguen les gents amb alegria festes», dins Obra Completa Revisada III

CQOTP: "La clau que obri tots els panys», dins Obra Completa Revisada I

LM: «Llibre de meravelles», dins Obra Completa Revisada II

ICG: Linventari clement de Gandia

MMP: «Manual del malalt perfecte», dins La lluna de colors. Obra completa 9

ATV: «L'amant de tota la vida», dins Obra Completa Revisada III

PE: «Poemes esparsos», dins Sonata d'Isabel. Obra Completa Io

GFG: "Gran foc dels garbons», dins Obra Completa Revisada III

S: "Saló», dins Vaixell de vidre. Obra Completa 8

SI: «Sonata d'Isabel», dins Vaixell de vidre. Obra Completa 8

CCO: "Ciutat a cau d'orella», dins Obra Completa Revisada I

OD: «L'ofici de demà», dins La lluna de colors. Obra Completa 9 
on et sentires trist com ningú t'ha sentit,

on et veieres, sol, destinat a la pena-

vertebren, com uns ossos, el dolor, el teu cos;

Al llarg de l'article ens centrarem, doncs, a analitzar com un espai carregat de significat $\mathrm{i}$, per tant, amb identitat pròpia, esdevé l'alteritat amb la qual interactua el jo poètic de Vicent Andrés Estellés. Estudiarem les diverses maneres d'enunciar la ciutat i la implicació d'aquestes enunciacions en el procés de construcció de l'alteritat urbana en contrast amb l'ambient domèstic.

\section{DUES PERSPECTIVES D'ENUNCIACIÓ}

Les postals urbanes creades per Estellés ens donen la possibilitat de catalogar els diferents punts de vista literaris amb què estan captades i la relació que es deriva, en conseqüència, entre la ciutat i el jo poètic. Enric Bou assenyalà aquesta divergència en les maneres de concebre l'espai reprenent Michel de Certeau en Linvention du quotidien (2013: 36):

\footnotetext{
El filòsof se servia de la concepció semiòtica que la ciutat «és un llibre que podem llegir, els lectors/autors en són els vianants-habitants i es dibuixa un doble enfocament: des de dalt (i des de fora), des de baix (i des de dins)».
}

Aquests dos punts de vista des dels quals albirar la ciutat coincideixen amb els dos relats que Vicent Andrés Estellés fa de la vida urbana. L'enunciació de la ciutat des de dalt respondrà a la figura de l'observador, o voyeur, i l'enunciació des de baix a la del practicant de la vila, o marcheur.

Vicent Andrés Estellés posa de manifest la determinació d'enfocar topològicament la seua obra amb l'objectiu de fixar les bases de la identitat del jo poètic i d'engegar la proposta literària que desplegarà al llarg de tota l'obra. Ja que cantarà la ciutat amb la finalitat de preservar entre els versos l'època viscuda a manera d'un gran inventari social, quasi antropològic, d'escenes quotidianes de la vida urbana.

\section{I LA CIUTAT DES DE DALT}

La figura del voyeur representarà en Estellés la possibilitat d'admirar la ciutat $\mathrm{i}$ tota la seua vida interior com un alter del qual no forma part. Aquesta mirada alteritzada radica en una posició d'observació zenital de la ciutat (De Certeau 1996: I04):

Caplletra 65 (Tardor, 2018), pp. 131-149 
El cuerpo ya no está atado por las calles que lo llevan de un lado a otro según una ley anónima; ni poseído, jugador o pieza del juego, por el rumor de tantas diferencias y por la nerviosidad del tránsito neoyorquino. El que sube allá arriba sale de la masa que lleva y mezcla en sí misma toda identidad de autores o de espectadores. [...] Su elevación lo transforma en mirón. Lo pone a distancia. Transforma en un texto que se tiene delante de sí, bajo los ojos, el mundo que hechizaba y del cual quedaba «poseído».

El jo poètic, per tant, abandona aquest conjunt heterogeni d'identitats que és la ciutat i esdevé un espectador en la grada de tot un món que es belluga sota els seus ulls (CQOTP 20I4: 38I):

\footnotetext{
Veig, des dels ponts, el lent, el trist, l'irremeiable crepuscle suburbà: veig despulles, residus; [...]

Veig cases, xemeneies: veig una polseguera abatent-se, tristíssima, sense forces, com un fracàs, silenciosa. Veig fracàs, veig silenci: veig, des dels ponts, el pobre, el diari estupor.
}

Açò provoca que, en termes lingüístics, l'observació de la realitat urbana es constate amb un ús habitual dels verbs de percepció sensorial, especialment «veure», o «oir/sentir», sota la fórmula «veig des de (un lloc) + una escena o un lloc», com mostren molts dels poemes.

Linterés i la temptació per narrar el món de portes enfora ens remet a Digues que mestimes encara que sigui mentida, on Montserrat Roig, salvant les distàncies que el gènere i la classe social estableixen, fa ús de la vista a vol d'ocell sobre Barcelona. La reclusió femenina a les galeries de l'Eixample que Roig explica recorda l'estada interior del jo poètic d'Estellés que s'aboca a la finestra. Però malgrat les concomitàncies, la veu poètica d'Estellés gaudeix d'una posició voluntària que contrasta amb la dels personatges de Roig. Ja que com diu l'autora «les galeries estan fetes per als contemplatius, però també per als qui havien de viure darrere del món, darrere del carrer, és a dir, les dones de la burgesia [...]» (Roig 20IO: 198).

Fet i fet, Estellés relata una ciutat contemplada des del panòptic de l'àmbit domèstic, un espai immediatament consecutiu al jo poètic. Des del distanciament metafòric de la ciutat que propicien aquests indrets floreix la idea del jo i de l'altre, i es defineixen els rols d'observador i món observat (LM 2015: 309):

Mire des de l'altura

del dia i l'any aquells, adorables tossals,

cossos, noms, dies, fúria. 
Irene Mira Navarro

Entre la llunyania i la intimitat: l'enunciació de l'espai urbà en Vicent Andrés Estellés

La primera talaia des d'on s'albira la realitat urbana és un dels espais per excellència en la poesia del de Burjassot, la casa. En el procés d'escriptura d'obres com "Coral romput» o La nit la llar és l'abric i alhora l'obertura des d'on copsar la ciutat que viu portes enfora. El poemari L'amant de tota la vida conté un poema de títol clarificador pel que fa a la naturalesa de lloc elevat que és la casa: «El primer pis, venint del cel, era el nostre». En una altra composició, la situació privilegiada del pis familiar al capdamunt de la ciutat propicia versos com aquests (ICG 20I2: 69):

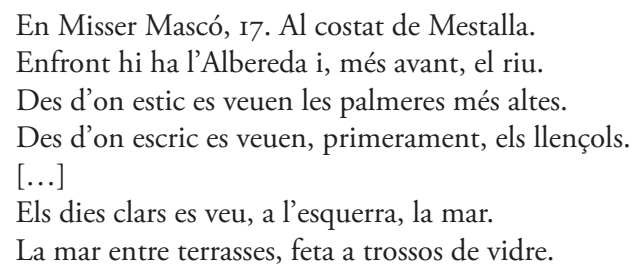

El component d'intimitat que té la llar la defineix com el lloc de la interioritat del subjecte, l'indret quotidià on radica la nostra manera d'habitar el món. En aquest sentit, diversos estudis posen de manifest la relació entre el jo i la casa, o més concretament, entre el cos i la casa, com dos espais concatenats que protegeixen i abriguen a mode de pell —Edward Hall (2013), Marta Segarra (20I4) i Carla Pasquinelli (2006). El vincle entre la casa i el cos respon a la idea de proximitat abans exposada, el lloc domèstic actua com a correlat del jo poètic perquè és l'espai més immediat al cos. En l'enfocament topològic en què ens movem la idea de centralitat resideix en el cos del subjecte i es projecta en la llar gràcies al concepte d'habitar. Marc Augé (I993) i Michel Foucault (20IO) afirmen que el cos és el primer espai habitat, i Augé va més enllà i postula que, a més, és «un espacio habitado en el que no dejan de actuar relaciones de identidad y de alteridad» (Augé I993: 20-2I). En termes d'espacialitat, l'alteritat, doncs, emergeix portes enfora de l'ambient domèstic, ja que com explica Bernhard Waldenfels (2004: 28):

\footnotetext{
se origina en un peculiar deslinde, una delimitación hacia dentro y hacia fuera, por la que no se constituyen simplemente dos lugares de igual valor, sino un adentro y un afuera, una zona interior y una exterior.
}

Aquesta percepció de proximitat íntima dels llocs domèstics ha trobat en el text literari el suport on vessar la sensibilitat derivada de l'experiència d'habitar perquè com Gaston Bachelard (2013: 36) afirmà «en los poemas, tal vez más que en los recuerdos, llegamos al fondo poético del espacio de la casa». 
Irene Mira Navarro

Entre la llunyania i la intimitat: l'enunciació de l'espai urbà en Vicent Andrés Estellés

Així ocorre en Estellés, on poemaris com Primera soledad, La nit, La clau que obri tots els panys o L'inventari clement de Gandia, donen una entitat quasi ontològica al concepte de llar, la qual cosa crea un alt grau d'afinitat entre l'espai domèstic i el jo poètic (ICG 20I2: 72):

Sí, Misser Mascó, I7. No és el títol d'un llibre:

és el meu domicili. És el món. És ma casa.

Ma casa és una casa entre altres vint-i-nou.

Sí, Misser Mascó, I7. És molt més que una adreça;

és també, més que un llibre: és tota la meua obra.

Tota la meua vida entre quatre parets.

Les quatre parets llises i clares de ma casa.

En contrapartida, un alt grau d'identificació entre el subjecte i la llar n'alteritza la relació amb el món urbà, aquest distanciament es concep com una conseqüència del joc dialèctic entre el subjecte i l'entorn que observa.

Si bé els espais no són profundament antagònics, el lloc íntim de la llar té uns límits molt clars que materialitzen la diferència entre l'interior i l'exterior domèstic i marquen una fita gairebé metafísica que concep allò exterior a la llar com alié al jo poètic. Com explica Carla Pasquinelli (2006: I06):

Puertas y umbrales no son sólo barreras, sino también pasos. Zonas de tránsito, tanto de entrada como de salida, cuya función no radica sólo en distinguir dos regiones distintas del espacio, sino también en hacer de intermediaria. Lugares de metamorfosis y transformaciones que marcan el paso de un mundo a otro.

Les obertures de la llar i altres regions de passatge, com els terrats o el buc de l'escala, faciliten una experiència liminar que fa fluir el contacte entre el jo i la ciutat. Marta Segarra, en la línia de Pasquinelli, estudia la funció simbòlica d'aquest fet liminar en relació amb les geografies íntimes que també són determinants en el contacte d'Estellés amb la ciutat. Segons l'autora (20I4: 9):

ens adonarem que [l'habitació, la casa i el carrer], en lloc de ser compartiments estanc i atès que les seves fronteres estan ben foradades, aquests tres espais distints constitueixen en realitat vasos comunicants.

Així doncs, les esmentades obertures de la llar i altres regions de passatge són un element recurrent en els poemaris que faciliten l'experiència liminar entre el jo i la ciutat i emfasitzen la presència de la vida del carrer a través d'aquests accessos en la poesia d'Estellés (CQOTP 20I4: 404): 
Fins on estic arriba la música del ball.

També, de tant en tant, s'ou el xiulit del tren,

s'ou el clàxon d'un cotxe. I res més. O poc més.

[...]

Tot açò és pel crepuscle: el vespre del diumenge.

O més aviat el contrari (CQOTP 20I4: 4II):

Escolte. Ja no sonen les trompetes del ball.

Ara hi ha un gran silenci, Isabel se n'ha anat

a la cuina. Estic sol. Estic sol al despatx.

En «Un amor, uns carrers» el fet amorós és l'element protagonista que relliga el món interior i l'exterior gràcies a la naturalesa comunicant de què gaudeixen els llocs on es desenvolupa (LM 20I5: 242):

\footnotetext{
Tots els amors, l'amor; l'amor, tota la vida. Jo no sé si està clar; per a mi sí ho està. Mire, des del balcó, el carrer solitari.

Després vindran parelles, així que caiga el dia.

[...]

Sempre torna la vida, si se'n va alguna volta.

No estic massa segura; jo crec que no se'n va.

O crec que sempre torna. M'agrada, des de casa, darrere dels cristalls, contemplar el carrer.
}

Les estrofes posteriors palesen la comunicació entre la vida de fora observada des de la finestra i la interior on, metafòricament, la pobresa recorre l'esquelet de l'edifici amerant la casa de la tristor de «contemplar solament la vella i alta imatge / en un silenci dens i poblat de records». L'alegria generada per l'amor ancorat als carrers és desnonada de la llar per a donar pas a la pobresa provinent de la ciutat. Aquesta metonímia de la postguerra urbana assalta l'esfera de la casa (LM 20I5: 244):

La pobresa pujava lentament per l'escala.

[...]

Se t'ompli el menjador novament de penombres.

Mires per la finestra. Veus les lentes parelles,

aquella nit no sopes i plores en el llit.

Com ja hem apuntat, l'elevació geogràfica del món domèstic proporciona una vista panoràmica que permet concebre València des del llindar domèstic sota diversos prismes. En alguns casos la ciutat és un correlat dels temps de postguerra i en altres és l'espai de les trobades amoroses i la quotidianitat. El poema «Cant de Vicent» encarna 
Irene Mira Navarro

Entre la llunyania i la intimitat: l'enunciació de l'espai urbà en Vicent Andrés Estellés

molt bé la segona apreciació, ja que com destaca Enric Bou, al «Cant de Vicent» hi ha desdoblament de veus: "la veu que ha d'escriure un "cant a València" i una altra més atenta a la petitesa, a l'experiència de la ciutat viscuda» (2013: 53). Aquesta polifonia respon paral-lelament a una doble enunciació de València: d'una banda, la ciutat observada per la veu que l'ha de cantar i, de l'altra banda, la ciutat viscuda i trepitjada des de baix (2013: 54):

Aquesta ciutat ideal es construeix des d'una perspectiva relacionada amb qüestions que he tractat abans. La ciutat es veu des de dalt i des de fora. Davant d'aquesta possibilitat, el poeta veu una altra ciutat més íntima, potser la veritable ciutat.

Tot un mosaic d'escenes quotidianes conformen la vida que el poeta descriu des de casa estant, ja que «[...] tota la vida [...] anava per València, pels carrers de València». Hi ha dos eixos temporals, passat i present, que lliguen en paral.lel els espais recordats pel jo poètic i els observats en el moment d'escriure'ls. «Els carrers que creuava una lenta parella», "la casa que estrenàreu», "el metge que buscàveu», es contraposen a les ràfegues de present que mostren la ciutat material que és a l'altra banda de l'ampit (LM 2015: 27I):

\footnotetext{
Veus, des del menjador, per la finestra oberta,

Benimaclet ací, enllà veus Alboraia,

escoltes des del llit les sirenes del port.

De bon matí arribaven els lents carros de l'horta.

Els xiquets van a l'escola. S'escolta la campana

veïna de l'església.
}

El segon espai des del qual Estellés efectua la vista panoràmica de la ciutat és el terrat, el qual gaudeix de més entitat espacial que les finestres i els balcons però alhora en recull la naturalesa liminar. Els versos de Manual del malalt perfecte il.lustren el definitiu distanciament de la ciutat propiciat per l'alçada (MMP 1986: 190):

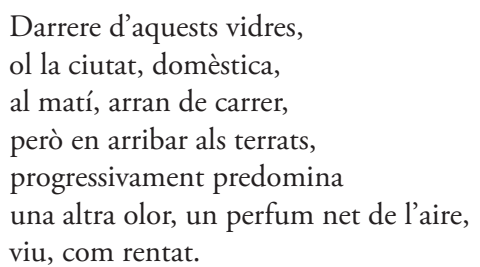

Des d'ací la ciutat es manifesta en els versos d'Estellés com una realitat de la qual el jo poètic no participa però sí que hi existeix un lligam (CQOTP 20I4: 37I): 


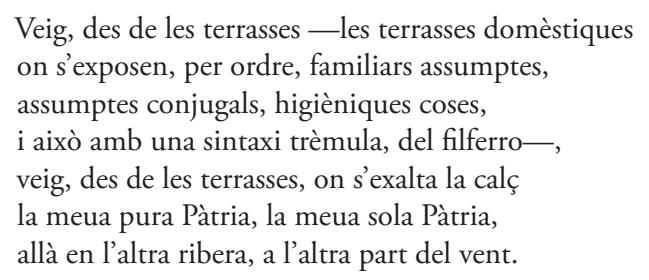

Aquesta part de la casa és la regió de trànsit entre l'interior i l'exterior més dilatada, ja que es troba a cavall entre la domesticitat i el món públic. Són uns llocs permeables a la vida del carrer que "permeten anar una mica fora sense sortir del tot de la ciutat, a una mena d'extraradi superior, una perifèria urbana que no és al voltant de la ciutat, sinó a sobre [...]» (Delgado \& Juan 200I: 17). Versos com els següents fan indestriables els terrats de l'experiència zenital de la ciutat i de la presència d'elements provinents de l'àmbit domèstic (ATV 20I6: I72):

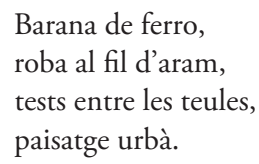

Tanmateix, aquests indrets tenen una entitat quasi sagrada en ser considerats els llocs de l'amor. Hi acullen les trobades dels amants justament per la naturalesa liminar que tenen, la qual és capaç d'afavorir un amor semipúblic en un espai perifèric, en termes de Delgado \& Juan (20II: I6):

separen les persones de la quotidianitat que omple els carrers de la ciutat. No mostren, només insinuen, donen a imaginar, i aquesta semiinvisibilitat els converteix en autèntics racons amagats, gairebé secrets, que només desvetllen el seu misteri a qui està disposat a enfilar-se a les alçades.

Com veiem en aquests versos (SI I999: I87):

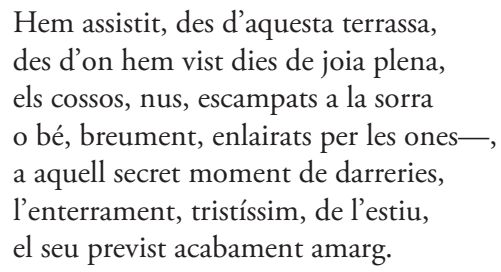

L'especial consideració que tenen els llocs de l'amor en la poesia estellesiana ens permet etiquetar-los sota el concepte de «cronotopies de la intimitat». Les baranes del riu, els cinemes o les terrasses estan específicament dotats com a centres afectius que 
Irene Mira Navarro

Entre la llunyania i la intimitat: l'enunciació de l'espai urbà en Vicent Andrés Estellés

es defineixen com «una especie de punto nodal de la trama, que tiene una dimensión configurativa, por cuanto inviste de sentido - $y$ afecto - a acciones y personajes, que asumirán por ello mismo una cierta cualidad» (Arfuch 2005: 255). En conseqüència, per la naturalesa cronotòpica i semiíntima que tenen els terrats en Estellés, són llocs propicis per a les trobades amoroses (S 1983: 23I):

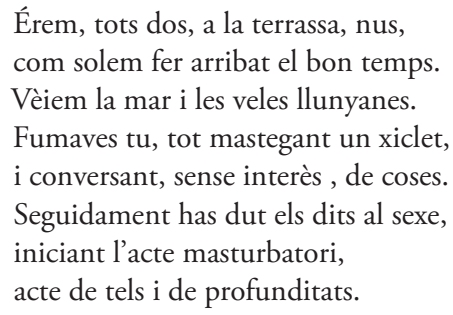

A més, l'ingredient cronotòpic es reforça amb la simbologia de les escenes nocturnes de la nit de sant Josep que fa dialogar l'experiència d'un temps passat amb la ciutat (LM 20I5: 288 i 24I):

\footnotetext{
L'un al costat de l'altre, contemplàvem València.

Vaig sentir el teu braç que buscava el meu braç.

Fa deu anys, fa vint anys, fa trenta anys, jo no ho sé.

Era en una terrassa humil en els afores.

Tots els veïns pujaren i miraven València.

Els agradava molt la nit de Sant Josep.

Les carcasses obrint-se en el cel de la fira.

Tota València en flames la nit de Sant Josep

Mentre féieu l'amor en aquella terrassa.
}

El panòptic des d'on el jo poètic contempla el món està marcat per l'experiència de la frontera entre l'interior i l'exterior, el domèstic i el social. S'hi genera, doncs, una dialèctica entre el pròxim i el distant que determina la mirada que s'aboca sobre la ciutat i la relació que s'hi estableix. Així, el món urbà és admirat quasi museísticament, des de la frontera domèstica que el jo poètic encara no ha creuat i que permet objectualitzar-lo com un ens diferent que desperta admiració i curiositat. Mentrestant, la poètica d'Estellés conté una altra perspectiva de la ciutat que comença a prendre forma en dinamitar les fronteres adés esmentades i baixar a la realitat del carrer com veurem tot seguit. 


\subsection{LA CIUTAT DES DE BAIX}

De la ciutat contemplada a la ciutat viscuda arran de terra no hi ha tan sols un canvi de perspectiva i una alteració en el joc de les distàncies, sinó una altra experiència de l'espai urbà. És per això que una vegada analitzada la figura del voyeur hem de fixar la vista en la del marcheur, que abandona l'interior de la llar i practica la ciutat des de la proximitat (Arfuch 2013: 4):

La diferencia entre interior y exterior guarda cierta semejanza con la que media entre distancia y proximidad, entre la panorámica desde el avión y el «abajo» de la muchedumbre, de los remolinos de la circulación y la respiración de la calle.

Aquest canvi de perspectiva altera la dialèctica de distàncies entrellunyà i pròxim, i té una dimensió que no podem obviar: si fins ara parlàvem de la ciutat percebuda, ara es tracta de la ciutat viscuda en un temps concret.

La idea d'exterioritat ens porta a analitzar la representació de la vivència concreta dels espais que hi ha portes enfora de la casa, és a dir, del carrer. Es passa així d'una relació simplement visual a un lligam quasi físic amb l'entorn urbà que tot seguit analitzarem. En aquest sentit, és evident, doncs, la centralitat del subjecte que oscil.la entre els conceptes d'alteritat-identitat, exterior-interior i dalt-baix. Ara el jo poètic s'acosta a la realitat urbana (CCO 20I4: II):

Sent la meua ciutat interior, i em puja

un baf arqueològic. Una humitat de cova,

el bufet d'un alé de segles i sarcòfags,

En descendir a caminar la ciutat i a relatar-ne les vives passejades i deambulejos, l'autor ens ofereix una perspectiva pròxima a les relacions que s'hi desenvolupen i de les quals pot formar part. En aquest moment, doncs, la ciutat ja no és entesa com una alteritat que s'observa des de dalt, sinó com una matriu que alberga alteritats on es troba immers el subjecte (Arfuch 2013: 5):

lugar de encuentro con el Otro en su más rotunda otredad —étnica, lingüística, cultural, sexual—, habitada por los nombres — calles, plazas, barrios, monumentos, edificios, comercios- en una cartografía caprichosa que une acontecimientos trascendentales de la historia con remotas geografías. 
Irene Mira Navarro

Entre la llunyania i la intimitat: l'enunciació de l'espai urbà en Vicent Andrés Estellés

Com si es tractara d'un mosaic, les ciutats són un conjunt de tot el que esdevé als barris, les places, els mercats o els solars i així es relata als versos del poeta de Burjassot. Per aquest motiu, parlar de la ciutat practicada des de dins equival a rastrejar les escenes i les narracions de la quotidianitat urbana (OD 1986: 107):

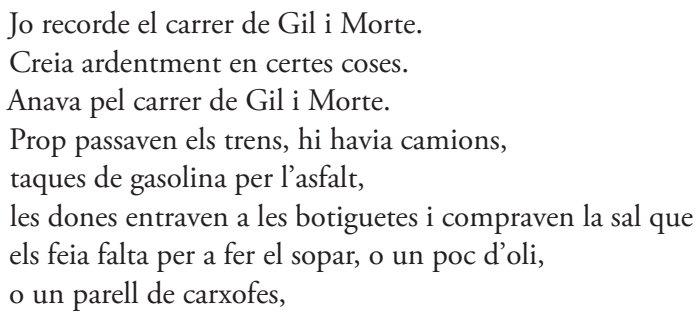

Com ja hem advertit anteriorment la representació espacial és un mecanisme literari emprat pel poeta amb un doble objectiu: d'una banda, obrir un marc afectiu i cultural compartit amb el receptor $i$, d'altra banda, vehicular una sèrie de significats socials que l'espai porta integrats. Perquè la identificació es porte a terme, els espais poetitzats han de ser pròxims al públic lector; per això Estellés aplega un seguit de llocs que denominarem "geografies de la quotidianitat».

Alicia Lindón les defineix com el conjunt d'espais per on es mou la vida dels subjectes, el qual conforma la seua identitat i la del col-lectiu del qual formen part (2006). Aquest concepte, pres de la Geografia Cultural, ens ajuda a entendre l'espacialització de l'univers poètic estellesià en una xarxa de punts com els estudiats fins ara. El poeta narra subjectivament els llocs i el que s'hi esdevé: «circunstancias —en aparienciabanales pero ricas en contenido por condensar claves socio-culturales empleadas en la construcción del sentido del lugar» (Lindón 2006: 434). A tall d'exemple, en aquest poema la veu poètica desdoblada en un tu espill explica un recorregut (PE 1999: 159):

\footnotetext{
S'AGAFAVA el tramvia 23. El tramvia,

Solemnement, pujava el vell pont dels Serrans.

Vares amar València, amares la ciutat,

Així, pujant pel pont, veient créixer les torres.

Arribaves al poble en aquell 23.

Miraves per les baranes sense massa interés.

Entraves pel carrer dels Serrans; més avant,

Aquell carrer solemne dels Cavallers, que diuen
}

En relació amb els indrets representats, el poema «Cos mortal» il.lustra amb claredat la fragmentació dels seixanta-nou topònims de València que creen la xarxa 
Irene Mira Navarro

Entre la llunyania i la intimitat: l'enunciació de l'espai urbà en Vicent Andrés Estellés

topològica que dóna sentit a bona part de la ciutat estellesiana. Unes localitzacions referides amb el topònim popular que activa, en paraules de Vicent Salvador, «un contrast que justifica la composició i fa sobresortir el valor d'autenticitat que connoten els topònims tradicionals, no infectats per la coentor i l'oportunisme oficialista» (I986: 595) i que enllaça amb els preceptes explicitats al Gran foc dels garbons (GFG 2016: 430):

Sempre que passe pel carrer dels pobres, que li han posat el nom d'un militar, em sé poble, em sé pols, ossos de música.

O bé a Poemes esparsos (PE 1999: I59):

No dic una València culta monumental revisc una València dramàtica o banal és com si begués l'aigua breument en un didal.

Un de vegades és cast i sentimental

Salvador apunta que l'ús dels topònims i la pràctica interior de la ciutat correspon al desig del poeta de teixir un canal d'identificació amb l'enciclopèdia cultural del públic, com un «factor productor de sentit poètic comunicable al receptor» amb el qual pretén connectar (I986: 593).

Els espais recreats en els versos responen a la intenció d'evidenciar el sentiment d'unió del jo poètic a determinat segment social tot fent esment a la realitat senzilla i quotidiana de la vida del poble. Com si d'un ham es tractara l'enunciació de la ciutat, de l'horta o dels topònims permet que el públic s'hi identifique i projecte en la literatura una part de l'experiència. Francesc Parcerisas precisa aquesta idea (2004: 53):

\footnotetext{
I paga la pena de remarcar que el lligam entre l'imaginari col-lectiu i el de l'escriptor és essencial si no volem crear un abisme i un distanciament que per força hauran d'engavanyar-ne la literatura tot convertint-la només en un producte de consum i no, com suggeria Auden, en una eina de llibertat, aprenentatge i coneixement.
}

El retrat dels espais de la quotidianitat obeeix al desig d'identificació amb les escenes i el que hi ocorre per a activar el marc enciclopèdic compartit. Lluís Meseguer reprodueix les següents paraules de Vicent Andrés Estellés en un article a propòsit de la relació entre poesia, territori i política: «Creo que mis libros, en el fondo y aun en la superficie, no son otra cosa que una meditación [...] sobre lo que ha sido, es y deberá ser con todas las rectificaciones posibles la vida del País Valenciano» (2013: 6I5). No es tracta, doncs, d'afirmar que la poesia d'Estellés és un pamflet polític, sinó que és una obra on gràcies a la informació que es llig a través de l'espai s'imbrica una concepció històrica, social i política.

Caplletra 65 (Tardor, 2018), pp. 131-149 
Irene Mira NAVARro

Entre la llunyania i la intimitat: l'enunciació de l'espai urbà en Vicent Andrés Estellés

Malgrat tot i un cop més, aquest mosaic de geografies quotidianes alça acta de la vida dels carrers gràcies a un element central en la poesia estellesiana, la temàtica amorosa. L'enfocament afectiu pren forma en les parelles lentíssimes i en la narració en primera persona d'escenes amoroses al mapa de València per a ampliar la connexió íntima amb els espais. Versos com els de «Goig del carrer» relliguen l'esfera afectiva a l'embadocament que provoca el passeig urbà (CCO 20I4: IO5):

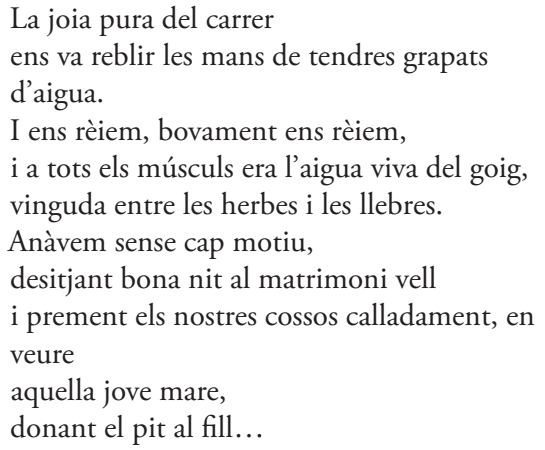

El fet d'enunciar el recorregut i el desplaçament crea el circuit per on transita el jo poètic (De Certeau I996: 32). Per aquest motiu, l'acció de narrar els carrers de l'amor és un mecanisme que Vicent Andrés Estellés fa servir per guanyar els carrers a les tenebres de la postguerra. "Coral romput» i el Llibre de meravelles són dues de les peces amb més presència de la veu poètica caminant pels carrers (CQOTP 20I4: 386):

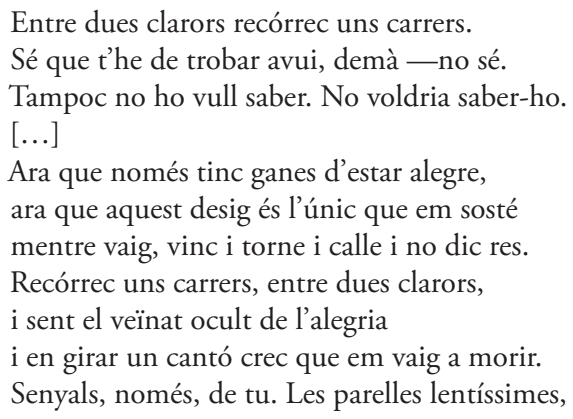

Mentre aquest jo pòetic a la recerca de l'estima poetitza l'espai urbà es configura un plànol literari dels espais practicats on s'engloben els recorreguts, o tour, i algunes referències a llocs concrets (De Certeau I996: I32). Així doncs, veiem com l'amor és en molts poemes el fet que activa el recorregut i en determina els punts creant un «mapa sentimental de la seva experiència de la ciutat» (Bou 20I3: 53) com veiem en aquests versos: 


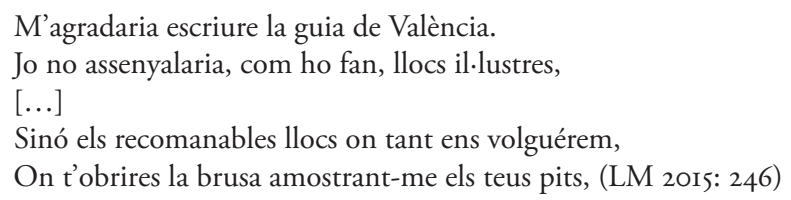

\section{CONCLUSIONS}

Els versos que ací hem analitzat mostren les dues vies d'accés a la ciutat que el poeta de Burjassot fa servir per a conquerir l'espai. Si bé en un primer moment la ciutat és concebuda com una alteritat és perquè aquesta esdevé objecte de contemplació i anàlisi. Mentre que, posteriorment, canvia el punt de vista de l'enunciació i l'espai urbà ja no és concebut, sinó viscut. Assistim, doncs, a dues maneres d'establir relacions amb l'espai i a dues maneres de poetitzar el fet urbà, ja que la perspectiva del jo poètic el fa moure's entre observador i participant. Aquesta dialèctica entre llunyania i proximitat estableix un correlat amb els conceptes d'identitat i alteritat encarnats en representacions espacials. De manera que el lloc domèstic presenta en els poemaris un centre irradiador d'identitat pel fort lligam establert amb la dimensió corporal del jo poètic. I l'emergència de l'alteritat té lloc en el tractament de l'entorn urbà com a espai concebut i practicat. En definitiva, un mecanisme que permet posar en diàleg la constitució de l'esfera íntima i la col-lectiva en la poesia estellesiana.

Irene Mira Navarro

Universitat d'Alacant

irene.mira@ua.es

ORCID 0000-0003-3096-1366

\section{REFERÈNCIES BIBLIOGRÀFIQUES}

Andrés Estellés, V. (I983) Vaixell de vidre. Obra Completa VIII, València, 314.

- (1986) La lluna de colors. Obra Completa IX, València, $3 \mathrm{i} 4$.

- (I999) Sonata d'Isabel. Obra Completa X, València, 3i4.

- (2012) L'inventari clement de Gandia, València, Edicions 96.

- (20I4) Obra Completa Revisada I, València, 3i4.

- (20I5) Obra Completa Revisada II, València, 3i4.

- (20I6) Obra Completa Revisada III, València, 3i4. 
Irene Mira Navarro

Entre la llunyania i la intimitat: l'enunciació de l'espai urbà en Vicent Andrés Estellés

Alejos García, J. (2006) «Identidad y alteridad en Bajtín», Acta poética, 27, pp. 45-6I. AugÉ, M. (1993) «Espacio y alteridad», Revista de Occidente, I4O, pp. I3-34.

Arfuch, L. (2005) «Cronotopías de la intimidad», dins L. Arfuch (ed.), Pensar este tiempo. Espacios, afectos, pertenencias, Buenos Aires / Barcelona / Mèxic, Paidós, pp. $237-290$

- (20I3): «La ciudad como autobiografía», Bifurcaciones. Revista de estudios culturales urbanos, I3, pp. I-I4

Bachelard, G. (2013) La poética del espacio, Mèxic, Fondo de Cultura Económica (I4a reimpressió).

Barthes, R. (1993) «Semiología y urbanismo», dins La aventura semiológica, Madrid, Paidós, pp. 257-266.

Bou, E. (2013) La invenció de l'espai. Ciutat i viatge, València, Publicacions de la Universitat de València.

Cosgrove, D. (2002) «Observando la naturaleza: el paisaje y el sentido europeo de la vista", Boletin de la A. G. E, 34, pp. 63-89.

De Certeau, M. (1996) La invención de lo cotidiano I, Artes de hacer, Mèxic, Universidad Iberoamericana.

Delgado, M. \& A. Juan (20II) «Introducció: entre el cel i la terra», dins Terrats de Barcelona. Entre el cel i la terra, pp. I4-I9.

GimÉneZ, G. (1999) «Territorio, cultura e identidades. La región socio-cultural», Estudios sobre las culturas contemporáneas, 9, pp. 25-57.

Hall, E. (2013) La dimensión oculta, Mèxic, Siglo Veintiuno Editores.

Lefebvre, H. (2013) La producción del espacio, Madrid, Capitán Swing.

Lindón, A. (2006) «La espacialidad de la vida cotidiana: los hologramas socioterritoriales de la cotidianeidad urbana», dins J. Nogué \& J. Romero (eds.), Las otras geografias, València, Tirant lo Blanch, pp. 425-445.

- (2014) «El habitar la ciudad, las redes topológicas del urbanita y la figura del transeúnte», dins D. Sánchez González \& L. A. Domínguez Moreno, Identidad y espacio público. Ampliando ámbitos y prácticas, Barcelona, Gedisa, pp. 55-76.

Martínez Lorea, I. (2013) «Prólogo», dins H. Lefebvre, La producción del espacio, Madrid, Capitán Swing, pp. 9-30.

Martínez Gutiérrez, E. (2013) «Introducción», dins H. Lefebvre, La producción del espacio, Madrid, Capitán Swing, pp. 3I-52.

Meseguer, L. (2013) «Poesia i territori», dins M. Pérez Saldanya \& V. Salvador (eds.), L'obra literària de Vicent Andrés Estellés. Gèneres, tradicions poètiques i estil, València, AVL, pp. 615-652. 
Irene Mira Navarro Entre la llunyania i la intimitat: l'enunciació de l'espai urbà en Vicent Andrés Estellés

Parcerisas, F. (2004) «La quotidianitat en la poesia de Vicent Andrés Estellés», dins F. Carbó, E. Balaguer \& Ll. Meseguer (eds.), Vicent Andrés Estellés, Alacant, IIFV, pp. 49-64.

PAsquinelli, C. (2006) El vértigo del orden: la relación entre el yo y la casa, Buenos Aires, Libros de la Araucaria.

RoIG, M. (20Io) Digues que m'estimes encara que sigui mentida, Barcelona, Edicions 62.

Salvador, V. (I986) «Toponímia i semiòtica poètica: unes reflexions sobre l'escriptura estellesiana", dins Xè Col-loqui generalde la Societat d'Onomàstica: Ir d'onomàstica valenciana, pp. 592-595.

- (2016) «Els primers anys seixanta i el silenci editorial: de les meravelles als esbossos de relat», dins V. Andrés Estellés, Obra Completa Revisada III, València, 3i4, pp. 7-50.

Segarra, M. (20I4) L'habitació, la casa, el carrer, Barcelona, Centre de Cultura Contemporània de Barcelona.

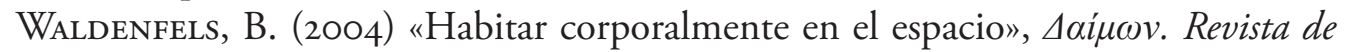
Filosofía, 32, pp. 2I-37.

Westphal, B. (2007) La géocritique. Réel, fiction, espace, París, Les Éditions de Minuit. 
